Article

\title{
Engineers Changing the World: Education for Sustainability in Romanian Technical Universities-An Empirical Web-Based Content Analysis
}

\author{
Lidia Alexa ${ }^{1, *}$, Veronica Maier ${ }^{2}$, Anca Șerban ${ }^{3}$ and Razvan Craciunescu ${ }^{4}$ \\ 1 "Gheorghe Asachi" Technical University of Iasi, Prof. Dimitrie Mangeron Blvd. no. 67, Iași 700050, Romania \\ 2 Technical University of Cluj-Napoca, Memorandumului Street 28, Cluj-Napoca 400114, Romania; \\ veronica.maier@enm.utcluj.ro \\ 3 Faculty of Economic Sciences, “Lucian Blaga” University of Sibiu, Victoriei Blvd. no. 10, \\ Sibiu 550024, Romania; anca.serban@ulbsibiu.ro \\ 4 The University Politehnica of Bucharest, Splaiul Independenței 313, Bucharest 060042, Romania; \\ razvan.craciunescu@upb.ro \\ * Correspondence: lidia.alexa@tuiasi.ro
}

Received: 24 January 2020; Accepted: 2 March 2020; Published: 5 March 2020

\begin{abstract}
Without a doubt, we are living in interesting times, characterized by both continuous economic development and improved standard of living, but also uncertainty, increased pollution, and environmental degradation, which means that, now, more than ever, global and consistent action is needed in order to create a more sustainable future. In this context, education in general and higher education in particular, face both, a significant challenge and a substantial role due to their formative function both in terms of mindset and practical tools. The main objective of our research was to explore the way technical universities in Romania have integrated into their curricula courses that aim at shaping sustainability competencies in engineering students. The study was carried out based on an exploratory empirical content analysis of the technical universities' curricula, in order to identify the courses, including sustainable development (SD)-related topics. The analysis covered 255 bachelor programs and 394 master programs with a total of 25,920 courses, both mandatory and optional. The results revealed that there are differences in approaching sustainability education between the universities and also faculties within the universities included in the sample, revealing a rather siloed approach.
\end{abstract}

Keywords: sustainability; education for sustainability; engineering education; sustainability competences; sustainable engineering; higher education institutions; Romania

\section{Introduction}

We are living in a period of globalization marked by constant change, aggravating environmental problems [1], diminishing resources, and increasing economic inequalities between humans. The best way to face and overcome these daunting challenges is by changing the existing paradigm and focusing on sustainability and sustainable development (SD).

Although sustainable development has become a globally accepted concept to guide interactions between nature and society [2], the literature provides various and sometimes divergent perspectives regarding the definition and components of $\mathrm{SD}$, and the practical applications follow the same trend.

However, SD's most frequently quoted definition comes from the Brundtland Report (1987) and is based on three pillars: Social community, economy, and environment. Here, sustainable development 
is defined as "a development that meets the needs of the present without compromising the ability of future generations to meet their own needs" [3].

In 2006, the European Union (EU) included the idea of sustainable development and sustainability into the "Strategy for an Extended Europe", which had the objective of creating sustainable communities and improving the living standards for present and future generations [4]. As a continuation of the EU's development strategy, the "Europe 2020 Strategy" was adopted in 2010 with the purpose of encouraging sustainable, rapid growth while also stressing the importance of education, innovation, training, and lifelong learning [5].

"The Agenda for Sustainable Development 2030", adopted in 2015, represents the EU's next step towards promoting SD. Structured around 17 SD goals, including sustainable economic growth and education as a means to improve the living conditions of individuals, communities, and entire societies, the agenda emphasizes the relevance of higher education in the struggle towards a better future [6]. Since higher education institutions are tasked with educating future professionals, and professionals manage a disproportionate amount of key resources [7], it is important for educators to incorporate SD into their curriculum.

Sustainability can be achieved through people making better decisions and recognizing the barriers consumers face when making sustainable choices. This shifts the focus to the training of specialists who manage the resources and educate the public on the choices that they make [7], elevating the importance of higher education institutions since they are charged with the key role of educating and changing the mindset of future professionals.

Since education represents a key change agent for the entire society [8], universities must function as research and learning centers [9]. Thus, higher education institutions should concentrate on interdisciplinary and experiential approaches, focused on addressing and solving problems using critical thinking [9]. However, higher education's role, aim, and mission are coming under increasing scrutiny. In particular, a university's policies and operations are valued on how far they currently contribute to a more sustainable society or perpetuate patterns of unsustainability. There is an ongoing debate concerning the nature of education in relation to the subject of sustainability in education (particularly in higher education). The results of this ongoing debate have produced "Education for Sustainability" (EfS) and "Education for Sustainable Development" (ESD). EfS and EDS aim to make human and cultural well-being more equitable, representing a process of learning how to make responsible decisions while also taking the environment, the economy, and the entire society into consideration [10].

Engineering educators around the world have simultaneously witnessed a significant shift in societal expectations of the engineering profession. There now exists an expectation for engineers to help address immediate and longer-term challenges related to sustainable development [11]. As a result, "sustainable engineering" has become part of the larger SD conversation.

Just like other terms related to sustainability, sustainable engineering has a variety of meanings as well. From UNESCO's perspective, "sustainable engineering is the process of using resources in a way that does not compromise the environment or deplete the materials for future generations. It requires an interdisciplinary approach in all aspects of engineering, and it should not be designated as a sole responsibility of environmental engineering. All engineering fields should incorporate sustainability into their practice in order to improve the quality of life for all" [12].

Another definition provided by Dowling (2010) includes a clear eco-efficiency focus: "Practices that promote environmental, social and economic sustainability through greater resource efficiency, reduced pollution and consideration of the wider social impacts of new technologies, processes, and practices" [13].

From our perspective, technological advancements for eco-efficiency must go hand-in-hand with changing the existing paradigm towards a consistent cultural and overall behavioral change.

The evolution of sustainability research, development, and university education can be seen as a reaction to the sustainability call made by various international conventions and stakeholders. 
This is also the reason why we focused our research on the topic of education for sustainability in higher engineering education. Although there are many studies targeting similar topics regarding the universities' role in developing and enhancing sustainability-oriented competencies [2,7,14-17], few of them are solely focused on analyzing the approach that technical universities have towards integrating sustainability and sustainable development into their curricula [11,18-24].

The paper's research objective was to explore whether Romanian technical universities have integrated SD in their curricula in order to enable students to develop sustainable thinking.

The analysis was conducted using the Romanian Ministry of Education List of Public Higher Education Institutions and is based on freely available information from each university's website.

The research is structured as follows: The first part presents the existing literature on sustainable development, the second presents the research methodology applied throughout the study, and the third presents the results of the exploratory empirical content analysis of the curricula. This included 25,920 mandatory and optional courses across 255 bachelor programs, 394 master programs, and 5 technical universities. The last part of the article presents the final conclusions. Lastly, we present the research's limitations and propose future research areas.

\section{Background on Sustainable Development \& Sustainability in Engineering Education}

\subsection{Origins of Sustainable Development}

There is a common perception that an industrialized country's wealth and advanced technology lead directly to sustainable development. However, the degree to which a country achieves a higher standard of sustainable development varies due to factors like culture and education [14].

Universities play a tremendous role in shaping the communities around them, especially since education is seen as a catalyst for helping society shift towards a more sustainable future. Therefore, the importance and also the pressure toward the educational sector, and in particular, to higher education, are constantly growing as it can be perceived as a seminal time for universities to step out of the ivory tower and connect with the societal needs and expectations.

Universities are considered ethically obliged to equip professionals with knowledge, skills, and competency necessary to address the evolving dynamics that individuals, organizations, and society face [25-27].

Society needs universities to provide an education that allows current and future generations to rethink and redesign their activities, get personal and professional skills in order to gain a sustainability vision and adopt sustainable practices. Even though the transition process of universities towards becoming more sustainable is ongoing [28-30], there is still a long way to go in this journey.

In 1990, an important foundational step towards sustainable universities occurred through The Talloires Declaration. The declaration comprised a ten-point action plan incorporating sustainability and environmental literacy in teaching, research and outreach programs. It was the first official statement made by university representatives pledging their commitment towards environmental sustainability in higher education and was signed by over 500 universities from more than 50 countries (including one Romanian institution—-the Polytechnic University of Bucharest) [31].

A growing body of literature shows the interest around SD in higher education and a university's role and responsibility to implement and teach sustainability. For example, Calder and Clugston (2016) state that in order for a university to be considered sustainable, it should include sustainability across eight areas, namely: (1) Research activity and scholarships, (2) curriculum, (3) opportunities for students, (4) working process, (5) recruitment of teaching and administrative staff, (6) development and rewarding system, (7) outreach and service, and (8) institutional mission, strategy and structure [32].

In the same context, Jones et al. (2010) propose "The $4 C^{\prime}$ " model that states that a sustainable university is the one that implements sustainability in the curriculum, campus, community, and culture [33]. 
Velazquez et al. (2006) present a more compelling image of what a sustainable university should look like, describing it as a higher education institution that focuses on addressing and reducing the negative effects consuming resources has over the environment, economy, and health. It also includes a four-phase process: (1) A sustainability vision, (2) an appropriate mission that incorporates sustainability, (3) a sustainability committee to create policies, targets, and objectives, and (4) sustainability strategies in education, research, outreach, and partnership and campus sustainability [34].

Adams et al. (2018) claim that an institution should incorporate sustainability, at least in the institutional culture [35]. However, Grecu and Ipina (2014) believe that the best scenario for a university is to implement a holistic vision and include aspects of sustainability and sustainable development in all the university's activities [36]. Despite that fact, most universities incorporate sustainability only into one area of activity. Some of them incorporate sustainability into management performance (i.e., vision, mission, strategy), others focus on research and education (i.e., programs, curriculum, teaching techniques), while others have created environmental policies, forming networks or establishing campus strategies.

\subsection{Education for Sustainable Development (ESD) and Sustainability in Engineering Education}

Education for Sustainable Development (ESD) has been recognized as being an essential instrument to achieve sustainable development. As a result, research into the practices of Higher Education for Sustainable Development (HESD) has increased over the last two decades.

The critical role of ESD started gaining worldwide recognition in 1992, when, during the Rio de Janeiro Earth Summit, the UN elaborated Agenda 21, an action plan for the 21st Century aimed towards sustainable development in which education was recognized as an essential path towards a more sustainable future [37].

The importance of ESD was also highlighted by the UNESCO framework-United Nations Decade of Education for Sustainable Development 2005-2014 (UNDESD), which had the goal to integrate principles, values, and practices of sustainable development into all aspects of education and learning [9]. As noted by UNESCO (2005), the focus of the Decade of Education for Sustainable Development is to have all educators include sustainable development concerns and goals in their own curriculum highlighting the responsibility of all university academics, not only those teaching in the environmental fields, to ensure that through their curricula and teaching, their students become competent in critically understanding and applying the principles of sustainable development.

Acting sustainably means that individuals first need to acquire sustainability-oriented competencies that can be developed through education and by introducing innovative forms of teaching and learning and reinforced through media communication and community actions. Sady et al. (2019) identified the core competencies of sustainability, namely: Responsibility (ethics), critical thinking, future orientation, communication and collaboration, systemic thinking and learning [16].

According to UNESCO (2017), ESD's goal is to develop competencies meant to empower individuals to reflect on their own actions, and to take into account their current and future social, cultural, economic, and environmental impacts, both from a local and global perspective. At the same time, individuals should also be empowered to act in a sustainable manner and to participate in socio-political processes, moving their societies towards sustainable development [38].

In this context, and considering the important link between a country's engineering capacity and its economic development [39], there is also a growing body of literature reflecting the need and urgency to change the current paradigms for engineering education towards sustainable development $[11,18,40]$. The goal is to produce 'sustainability literate' students who contribute to the changes required for a low carbon economy and a society which is low in the use of energy and raw materials and high in terms of intellectual capital, creativity, and capacity for collaborative working [41].

Sustainability, specifically with regards to engineering, is critically important for the broader sustainability movement. There are three main reasons to emphasize sustainable engineering: (1) 
Society is very familiar with engineering activities, (2) sustainable engineering has a significant role fueling economic growth and rising living standards, and (3) sustainable engineering profoundly impacts our natural environment [14].

Rosen points out as well that there are "several components to the manner in which engineering can be practiced sustainably in society", basically a series of requirements for achieving engineering sustainability which need to be taught: Sustainable resources, sustainable processes, increased efficiency, reduced environmental impact, and fulfillment of other aspects of sustainability [14].

Just like all the other concepts surrounding sustainability-related issues, when it comes to engineering education for sustainable development, there is no clear consensus on the definition or the list of desired competencies, skills, or learning outcomes.

In light of this observation, the World Federation of Engineering Organizations (WFEO), an organization that represents more than 30 million engineers from around 100 national engineering institutions, provided an all-encompassing definition where engineers play "an important role in planning and building projects that preserve natural resources, are cost-efficient and support human and natural environments" [18].

Focusing on engineering curricula, there are several ways to include sustainability issues. According to Mesa et al. [24] and Riley [42], universities can opt for: Stand-alone courses (dedicated courses related to sustainability topics) and curriculum integration (sustainability-related topics are integrated into existent courses).

Lozano et al. research revealed that there can be four approaches universities use in practice [43]: Specific SD courses [44-46], limited coverage of some environmental issues and material in an existing module or course [47], SD intertwined as a concept in regular disciplinary courses, tailored to the nature of each specific course [45-48] and SD as a possibility for specialization within the framework of each faculty [46].

In terms of the actual means of integrating sustainability in engineering education, previous research shows that although a multitude of SD-related course subjects have been introduced in higher education curricula over the last few years [49], when it comes to the curricula of the universities that teach engineering students, the focus is still on providing engineers knowledge to solve technological problems without taking into account, in many cases, the social and environmental impact of their work [50,51]. The research also points out that there is little strategic and systemic integration of sustainability into the curricula $[52,53]$. The main focus should be on educating engineering students to understand how their decisions as engineers influence the systems which they design [54].

This aspect is intrinsically connected with the fact that, at least at the bachelor level, the curriculum is already full [55], hence, as revealed by this research as well, it is more convenient for universities at this point to include sustainability disciplines at master's level, even if sustainability competencies should be integrated into the curricula of every educational level.

As part of the US Center for Sustainable Engineering study, Allen and others at the University of Texas at Austin, Carnegie Mellon University and Arizona State University have produced a comprehensive report based on a benchmark analysis regarding sustainable engineering education, namely accredited engineering programs across the US that incorporate sustainability concepts [52].

Based on the results of the questionnaires, and interviews conducted with representatives from 273 engineering departments (representing $20 \%$ of the contacted sample), the researchers concluded that there are four primary ways to incorporate sustainable engineering content and concepts into the curriculum:

- To develop dedicated sustainable engineering courses (48\%)

- To integrate sustainable engineering concepts into traditional engineering courses with the goal of broadening students' awareness and skill set $(23 \%)$

- To deliver classes which focus on the technologies predicted to be important in developing sustainable engineering solutions (such as carbon capture or solar power) $(14 \%)$ 
- To work in conjunction with a non-engineering department and create a cross-listed or interdisciplinary course offering (e.g., economics, policy development, social psychology) (15\%).

Eighty percent of the respondents included in the analysis stated that they are 'teaching either sustainable engineering-focused courses or integrating sustainable engineering material into existing courses' and most of the classes were taught to upper-level undergraduate and graduate students.

The author's strong statements set a tone for the future of engineering education: "We believe a long-term goal of 21st-century engineering education is to enable practicing engineers to incorporate tenets of sustainability into all phases of their practice, so that 'sustainable engineering' eventually equates with 'good engineering'" [52].

\section{Materials and Methods}

The main objective of our research was to explore the way technical universities in Romania develop and implement educational programs aimed at enabling engineering students to gain sustainability competencies, as there has been a great number of experts highlighting the importance of ESD in engineering schools and the importance of adapting and renewing engineering curriculums to contribute to a more sustainable future [11,18,23,24,40,56-58].

The research questions that guided the study were:

1. How are technical universities integrating SD-related subjects into their curricula for bachelor and master programs?

2. What are the most frequent sustainability-related subjects integrated into the curricula?

3. What are the engineering programs that most frequently include sustainability concepts in the curricula?

The research was conducted at five Romanian technical universities (for this study, we considered technical universities as universities that had over $50 \%$ of their programs in engineering) according to the Romanian Ministry of Education List of Public Higher Education Institutions included in the Government Decision (GD) no. 692/5 September 2018:

1. Polytechnic University of Bucharest (UPB)

2. Technical University of Civil Engineering of Bucharest (UTCB)

3. Technical University of Cluj Napoca (TUCN)

4. Technical University "Gheorghe Asachi" Iasi (TUIASI)

5. Polytechnic University of Timisoara (UPT)

The analysis was conducted using a two-step approach: First, a critical analysis on the literature discussing the concepts of sustainability, sustainable university, education for sustainable development, and the role of technical higher education institutions in shaping sustainability competencies in engineering students and secondly, an exploratory empirical content analysis of the five Romanian technical universities' curricula to identify the classes covering sustainable development-related topics.

There are three reasons we focused our research on Romanian technical universities: (1) There is an important connection between a country's engineering capacity and its economic development [39], (2) the importance of ESD for engineers is highlighted in the literature [23,44,45,56-58], and (3) the average number of engineering students enrolled in bachelor programs between 2014 and 2018 was 86,349 , representing $21 \%$ of Romania's entire student population [59].

Within the five technical universities included in the research, we further narrowed the analysis by selecting schools that offered programs dedicated to engineers, as some technical universities have schools with a non-technical profile, such as Faculty of Communication Sciences or Faculty of Humanities. Therefore, we included in the analysis 48 faculties, as shown below in Table 1. 
Table 1. Number of faculties and study programs included and excluded from the analysis.

\begin{tabular}{lccccc}
\hline & UPB & UTCB & TUCN & TUIASI & UPT \\
\hline & Included/Excluded & Included/Excluded & Included/Excluded & Included/Excluded & Included/Excluded \\
$\begin{array}{c}\text { No. of faculties } \\
\begin{array}{c}\text { No. of bachelor } \\
\text { programs }\end{array}\end{array}$ & $15 / 0$ & $5 / 2$ & $10 / 2$ & $11 / 0$ & $7 / 3$ \\
$\begin{array}{c}\text { No. of master } \\
\text { programs }\end{array}$ & $80 / 2$ & $20 / 0$ & $62 / 0$ & $55 / 3$ & $34 / 0$ \\
\hline
\end{tabular}

Considering that education for sustainability covers a wide variety of topics, and is subject to various interpretations, as mentioned earlier, we decided to adopt and follow an inclusive definition of sustainability used in previous research by $\mathrm{Wu}$ et al. [60]. This definition centers on the core understanding of a balance between economic growth, environmental carrying capacity, and sociocultural concerns, as well as association with a great regimen of topics with the universal theme nevertheless consisting of the triple-bottom-line-that is, social, environmental, and economic aspects. We have also analyzed the key sustainability-related topics and competencies listed in the literature: Systemic thinking, ability to solve problems (integrated resolution), working in an interdisciplinary group (collaboration), critical thinking, normative competence, self-knowledge, contextualization and vision of the future (anticipatory), and strategic competence [23].

After supplementary analysis, we further extended our search criteria to only use courses that included the following 42 terms that better fit the great new challenge for the engineer of the 21st century [61] (Table 2).

Table 2. Education for sustainability-related terms.

\begin{tabular}{|c|c|c|}
\hline Biodiversity & Human Rights & Climate Change \\
\hline Market economy & Community engagement & Natural resource \\
\hline Corporate citizenship & Natural resources management & $\begin{array}{l}\text { Corporate environmental } \\
\text { responsibility }\end{array}$ \\
\hline Corporate responsibility & Pollution management & $\begin{array}{c}\text { Corporate responsibility and } \\
\text { accountability }\end{array}$ \\
\hline Poverty prevention & $\begin{array}{l}\text { Corporate social responsibility } \\
\text { (CSR) }\end{array}$ & Race relations \\
\hline $\begin{array}{l}\text { Culture diversity and intercultural } \\
\text { understanding }\end{array}$ & Recycle & Renewable energy \\
\hline Ecology & Reuse & Ecosystem \\
\hline Rural development & Energy & Sustainability \\
\hline Environmental health and safety & Sustainable development & Environmental stewardship \\
\hline Sustainable growth & Equal opportunity & Sustainable procurement \\
\hline Ethics & Sustainable urbanization & Fair trade \\
\hline Greening & Gender equality & Waste \\
\hline Peace and human security & Risk management & Entrepreneurship \\
\hline Regeneration & Disaster prevention and mitigation & Communication \\
\hline
\end{tabular}

In order to carry out the research, we analyzed the university's website to identify the programs and the curricula listed for bachelor and master students. Similar methodologies based on a content analysis of the university websites were used by Khan (2013) to identify the offering and nature (scope) of sustainability accounting courses [62], Mustață et al. (2013) to identify which universities can contribute to incorporating sustainability in the formation of business students [63], and O'Byrne et al. (2015) to evaluate the curricula of programs granting degrees in sustainability [64]. 
The research team also analyzed the general strategies of the universities to determine to what extent sustainability and SD are incorporated.

The analysis was conducted between June 2019 and December 2019 and only considered the last available curricula for each program, in English, when possible. The content analysis followed the 42 terms previously listed and was intended to identify courses covering sustainable development related topics. The analysis focused on identifying courses that were fully dedicated to sustainable development-related topics as, in most cases, the title was suggestive and included one of the terms.

The curricula's content analysis distinguished between the compulsory/mandatory classes and the optional/elective classes for both bachelor and master programs.

The total number of classes, presented in Table 3, was determined by analyzing all the available curriculum listed on the faculty/departments' webpages and counting the number of classes offered, separately covering the mandatory and optional classes. The count did not include the (1) professional practice hours and (2) the hours dedicated to the elaboration of the bachelor/master thesis included in the curricula.

Table 3. Total course offering and sustainable development (SD)-related classes at the analyzed faculties.

\begin{tabular}{|c|c|c|c|c|}
\hline University & Faculty & $\begin{array}{l}\text { Bachelor (B) (Total } \\
\text { No. Classes/SD } \\
\text { Classes) }\end{array}$ & $\begin{array}{l}\text { Master (M) (Total } \\
\text { No. Classes/SD } \\
\text { Classes) }\end{array}$ & $\begin{array}{l}\% \text { SD Class from } \\
\text { Total (B/M) }\end{array}$ \\
\hline \multirow{17}{*}{ UPB } & Faculty of Electrical Engineering & $334 / 11$ & $128 / 13$ & $3.29 / 10.15$ \\
\hline & Faculty of Power Engineering & 711/95 & $270 / 84$ & $13.36 / 31.11$ \\
\hline & $\begin{array}{l}\text { Faculty of Automatic Control and } \\
\text { Computer Science }\end{array}$ & $203 / 17$ & $429 / 61$ & $8.37 / 14.22$ \\
\hline & $\begin{array}{l}\text { Faculty of Electronics, } \\
\text { Telecommunications and Information } \\
\text { Technology }\end{array}$ & $569 / 10$ & $285 / 1$ & $1.76 / 0.35$ \\
\hline & $\begin{array}{l}\text { Faculty of Mechanical Engineering } \\
\text { and Mechatronics }\end{array}$ & $872 / 30$ & $293 / 49$ & $3.44 / 16.72$ \\
\hline & Faculty of Engineering and & & & \\
\hline & $\begin{array}{l}\text { Management of Technological } \\
\text { Systems }\end{array}$ & $992 / 22$ & $515 / 73$ & $2.22 / 14.17$ \\
\hline & $\begin{array}{l}\text { Faculty of Biotechnical Systems } \\
\text { Engineering }\end{array}$ & $256 / 22$ & $129 / 33$ & $8.59 / 25.58$ \\
\hline & Faculty of Transports & $160 / 2$ & $58 / 4$ & $1.25 / 6.9$ \\
\hline & Faculty of Aerospace Engineering & $509 / 48$ & $151 / 22$ & $9.43 / 14.56$ \\
\hline & $\begin{array}{l}\text { Faculty of Material Science and } \\
\text { Engineering }\end{array}$ & $492 / 52$ & $166 / 33$ & $10.57 / 19.88$ \\
\hline & $\begin{array}{l}\text { Faculty of Applied Chemistry and } \\
\text { Materials Science }\end{array}$ & $631 / 100$ & $283 / 56$ & $15.85 / 19.79$ \\
\hline & $\begin{array}{l}\text { Faculty of Engineering in Foreign } \\
\text { Languages }\end{array}$ & $418 / 35$ & $149 / 32$ & $8.37 / 21.48$ \\
\hline & Faculty of Applied Sciences & $159 / 3$ & $80 / 5$ & $1.89 / 6.25$ \\
\hline & Faculty of Medical Engineering & NA & $50 / 2$ & $\mathrm{NA} / 4$ \\
\hline & $\begin{array}{l}\text { Faculty of Entrepreneurship, Business } \\
\text { Engineering and Management }\end{array}$ & $317 / 46$ & $183 / 45$ & $14.51 / 24.59$ \\
\hline & TOTAL & \multicolumn{2}{|c|}{ 9792/1006 } & $10.27 \%$ \\
\hline
\end{tabular}


Table 3. Cont

\begin{tabular}{|c|c|c|c|c|}
\hline University & Faculty & $\begin{array}{l}\text { Bachelor (B) (Total } \\
\text { No. Classes/SD } \\
\text { Classes) }\end{array}$ & $\begin{array}{l}\text { Master (M) (Total } \\
\text { No. Classes/SD } \\
\text { Classes) }\end{array}$ & $\begin{array}{l}\text { \% SD Class from } \\
\text { Total (B/M) }\end{array}$ \\
\hline \multirow{6}{*}{ UTCB } & $\begin{array}{l}\text { Faculty of Civil, Industrial and } \\
\text { Agricultural Constructions }\end{array}$ & $247 / 12$ & $157 / 13$ & $4.86 / 8.28$ \\
\hline & Faculty of Engineering Installations & $258 / 19$ & $91 / 14$ & $7.36 / 15.38$ \\
\hline & Faculty of Hydrotechnics & $329 / 43$ & $108 / 22$ & $13.06 / 20.37$ \\
\hline & $\begin{array}{l}\text { Faculty of Railways Roads and } \\
\text { Bridges }\end{array}$ & $80 / 15$ & NA & $18.75 / \mathrm{NA}$ \\
\hline & $\begin{array}{l}\text { Faculty of Engineering- Foreign } \\
\text { Languages }\end{array}$ & $254 / 6$ & NA & 2.36/NA \\
\hline & TOTAL & \multicolumn{2}{|c|}{$1524 / 138$} & $9.05 \%$ \\
\hline \multirow{11}{*}{ TUCN } & $\begin{array}{l}\text { Faculty of Architecture and Urban } \\
\text { Planning }\end{array}$ & $78 / 6$ & $41 / 4$ & $7.69 / 9.76$ \\
\hline & $\begin{array}{l}\text { Faculty of Automation and Computer } \\
\text { Science }\end{array}$ & $433 / 29$ & $290 / 2$ & $6.7 / 0.69$ \\
\hline & $\begin{array}{l}\text { Faculty of Automotive, Mechatronics } \\
\text { and Mechanical Engineering }\end{array}$ & $568 / 39$ & $263 / 63$ & $6.87 / 23.95$ \\
\hline & Faculty of Civil Engineering & $753 / 58$ & $243 / 31$ & $7.7 / 12.76$ \\
\hline & $\begin{array}{l}\text { Faculty of Machine Building } \\
\text { Faculty of Electronics, }\end{array}$ & $902 / 48$ & $290 / 52$ & $5.32 / 17.93$ \\
\hline & $\begin{array}{l}\text { Telecommunication and Information } \\
\text { Technology }\end{array}$ & $399 / 21$ & $194 / 16$ & $5.26 / 8.25$ \\
\hline & $\begin{array}{l}\text { Faculty of Materials and } \\
\text { Environmental Engineering }\end{array}$ & $455 / 63$ & $178 / 59$ & $13.85 / 33.15$ \\
\hline & Faculty of Electrical Engineering & $668 / 52$ & $123 / 17$ & $7.78 / 13.82$ \\
\hline & Faculty of Building Services & $76 / 5$ & $22 / 5$ & $6.58 / 22.73$ \\
\hline & Faculty of Engineering Baia Mare & $960 / 106$ & $188 / 48$ & $11.04 / 25.53$ \\
\hline & TOTAL & \multicolumn{2}{|c|}{$7124 / 724$} & $10.16 \%$ \\
\hline \multirow{12}{*}{ TUIASI } & Faculty of Architecture & $75 / 1$ & $5 / 1$ & $1.33 / 20$ \\
\hline & $\begin{array}{l}\text { Faculty of Automatic Control and } \\
\text { Computer Engineering }\end{array}$ & $238 / 12$ & $81 / 15$ & $5.04 / 6.17$ \\
\hline & $\begin{array}{l}\text { Faculty of Chemical Engineering and } \\
\text { Environmental Protection }\end{array}$ & $753 / 48$ & $124 / 66$ & $6.37 / 53.23$ \\
\hline & $\begin{array}{l}\text { Faculty of Civil Engineering and } \\
\text { Building Services }\end{array}$ & $352 / 8$ & $212 / 26$ & $2.27 / 12.26$ \\
\hline & $\begin{array}{l}\text { Faculty of Machine Manufacturing } \\
\text { and Industrial Management }\end{array}$ & $552 / 1$ & $190 / 12$ & $0.18 / 6.32$ \\
\hline & $\begin{array}{l}\text { Faculty of Electronics, } \\
\text { Telecommunications and Information } \\
\text { Technology }\end{array}$ & $252 / 1$ & $113 / 7$ & $0.4 / 6.19$ \\
\hline & Faculty of Electrical Engineering & $526 / 22$ & $75 / 18$ & $4.18 / 24$ \\
\hline & $\begin{array}{l}\text { Faculty of Hydrotechnics, Geodesy \& } \\
\text { Environmental Engineering }\end{array}$ & $299 / 41$ & $107 / 20$ & 13.71/18.69 \\
\hline & Faculty of Mechanical Engineering & $386 / 10$ & NA & $2.59 / \mathrm{NA}$ \\
\hline & $\begin{array}{l}\text { Faculty of Material Science and } \\
\text { Engineering }\end{array}$ & $278 / 6$ & $74 / 7$ & $2.16 / 9.46$ \\
\hline & $\begin{array}{l}\text { Faculty of Industrial Design and } \\
\text { Business Management }\end{array}$ & $381 / 12$ & $178 / 12$ & $3.15 / 6.74$ \\
\hline & TOTAL & \multicolumn{2}{|c|}{$5251 / 336$} & $6.4 \%$ \\
\hline \multirow{8}{*}{ UPT } & $\begin{array}{l}\text { Faculty of Architecture and City } \\
\text { Planning }\end{array}$ & $161 / 2$ & $50 / 7$ & $1.24 / 14$ \\
\hline & $\begin{array}{l}\text { Faculty of Automation and } \\
\text { Computers }\end{array}$ & $213 / 16$ & $113 / 10$ & $7.51 / 8.85$ \\
\hline & $\begin{array}{l}\text { Faculty of Industrial Chemistry and } \\
\text { Environmental Engineering }\end{array}$ & $229 / 53$ & $23 / 6$ & $23.14 / 26.08$ \\
\hline & $\begin{array}{l}\text { Faculty of Civil Engineering } \\
\text { Faculty of Electronics, }\end{array}$ & $410 / 35$ & $107 / 15$ & $8.54 / 14.01$ \\
\hline & $\begin{array}{l}\text { Telecommunications and Information } \\
\text { Technologies }\end{array}$ & $206 / 7$ & $80 / 6$ & $3.4 / 7.5$ \\
\hline & $\begin{array}{l}\text { Faculty of Electrical and Power } \\
\text { Engineering }\end{array}$ & $137 / 6$ & $26 / 2$ & $4.38 / 7.69$ \\
\hline & Faculty of Mechanical Engineering. & $252 / 16$ & $222 / 22$ & $6.36 / 9.9$ \\
\hline & TOTAL & \multicolumn{2}{|c|}{$2229 / 203$} & $9.1 \%$ \\
\hline
\end{tabular}


In some instances, the materials for analysis were not available online: Either the entire curriculum for a program was missing, or the curriculum published did not include the classes for all study years.

\section{Results and Discussions}

This section presents the main findings of the study through a detailed examination of the information gathered from the technical universities' websites and by using exploratory empirical content analysis. As mentioned in the research methodology, five universities and 48 faculties (as seen in Table 3) were included in the study and their curricula were analyzed, to identify course offerings related to topics of sustainability and sustainable development.

We started our study with a detailed analysis of the faculties and the programs which were examined according to their course offering. The researched faculties offer 255 bachelor programs and 394 master programs that all include, to a smaller or bigger extent, SD-related courses in their curricula, according to the criteria defined in the methodology section. The programs belong to different domains, the maximum number of specializations recorded within the analyzed universities being 12 at bachelor and 26 at the master level. Worth mentioning here is that for all faculties, an end-to-end bachelor program has eight semesters and an end-to-end master program has four semesters, the last one being mainly reserved for the thesis preparation. In all the analyzed universities, we have noticed that the number of SD-related courses differs between faculties, with a minimum of one course and a maximum of 106 courses at the bachelor level and a minimum of one course and a maximum of 84 courses at the master level.

Analyzing each university separately, we can see that at:

- UPB most SD-related classes, taken together for both bachelor and master, are offered at the Faculty of Power Engineering (SD-related classes represent $13.36 \%$ of all bachelor classes and $31.11 \%$ of all master classes) (Figure 1). The next faculty to follow is the Faculty of Entrepreneurship, Business Engineering, and Management (SD-related classes represent $14.51 \%$ of all bachelor classes and $24.59 \%$ of all master classes), a faculty which is particular to UPB as generally the purely technical universities in Romania, even though they offer courses related to management and business, they do not usually have a separate school in the university. In comparison to the SD classes that we found at the Faculty of Power Engineering that are mostly related to Environment and Pollution, the Faculty of Entrepreneurship, Business Engineering and Management offer SD classes on Corporate Social Responsibility, Market Economy, Human rights, Entrepreneurship, Communication or Fair trade. In terms of the general strategy of the University, there is only one reference to sustainability, related with social responsibility in the Strategic Plan of Institutional Development.

- UTCB most SD related classes, taken together for both bachelor and master, are offered at the Faculty of Hydrotechnics (14.87\% SD classes from total class offering, where SD-related classes represent $13.06 \%$ of all bachelor classes and $20.37 \%$ of all master classes) followed by the Faculty of Engineering Installations (SD related classes represent $7.36 \%$ of all bachelor classes and $15.38 \%$ of all master classes) (Figure 2). This result can be explained by the fact that the Faculty of Hydrotechnics offers at the bachelor level the specializations "Environmental engineering" and "Sanitary engineering and environmental protection" and at the master level a specialization directly targeting sustainable development, named exactly like that. The Faculty of Engineering Installations, on the other hand, offers the specializations "Appliances and equipment for atmospheric protection" at the bachelor level and "Competitive technologies for urban environment protection" and "Energy, comfort and sustainable development" at the master level. There are no references to sustainability and SD in the university's strategic plan for 2016-2020.

- TUCN most SD related classes, taken together for both bachelor and master, are offered at the Faculty of Materials and Environmental Engineering (SD related classes represent $13.85 \%$ of all bachelor classes and $33.15 \%$ of all master classes) with a percentage of SD classes of $19.27 \%$, which is due to the fact that it has a specialization at the master level entirely dedicated to sustainable development, called Engineering, The Right, and the Economy of Sustainable 
Development (Figure 3). Next faculty in line is the Faculty of Engineering Baia Mare $(13.41 \%$ SD classes from total class offerings, where $11.04 \%$ of all bachelor classes and $25.53 \%$ of all master classes are SD classes). This faculty offers, at the bachelor level, a specialization called Engineering and Environmental Protection in Industry, and at the master level, a specialization called Environmental Impact and Risk Assessment, were most of SD classes are taught. In terms of the general strategy of the university, the 2016-2020 strategic plan has references to financial sustainability and sustainable development, the latter being connected with the idea of reshaping the educational process to better respond to the real needs of the socio-economic environment.

- TUIASI most SD-related classes, taken together for both bachelor and master, are offered at the Faculty of Hydrotechnics, Geodesy, and Environmental Engineering (15\%—SD-related classes represent $13.71 \%$ of all bachelor classes and $18.69 \%$ of all master classes), closely followed by the Faculty of Chemical Engineering and Environmental Protection with 13\% SD classes (SD-related classes represent $6.37 \%$ of all bachelor classes and $53.23 \%$ of all master classes) (Figure 4 ). This number is higher than all others registered due to the fact that both faculties have Master programs in Environmental Management, Environmental Management and Sustainable Energy and Waste Management, Treatment and Recovery. At the same time, at TUIASI 17, courses had entrepreneurship in the title, most of the classes being included in the third and fourth year curricula, as a result of a university-wide project aiming at improving the entrepreneurial culture and competencies of the engineering students enrolled. In terms of the general strategy of the university, in the 2016-2020 strategic plan there is only one reference to financial sustainability and there is a list of objectives and strategies regarding environmental protection.

- UPT most SD-related classes, taken together for both bachelor and master, are offered at the Faculty of Industrial Chemistry and Environmental Engineering with a percentage of SD classes of approximately $23.41 \%$ from total class offerings (SD related classes represent $23.14 \%$ of all bachelor classes and $26.08 \%$ of all master classes) (Figure 5). This is somehow understandable as the name of the faculty indicates that there are a lot of specializations related to the environment, namely environmental protection. At a great distance from what constitutes SD class offerings follows the Faculty of Civil Engineering (9.67\% SD classes from total class offerings), which offers a specialization at the bachelor level also related to environmental protection (SD-related classes represent $8.54 \%$ of all bachelor classes and $14.01 \%$ of all master classes). In terms of general strategy, the Polytechnic University of Timisoara (UPT) has the most detailed view on sustainability from all the analyzed universities. The university places sustainability as a necessity in contemporary context and it plans to find ways to reduce resource waste in all activities.

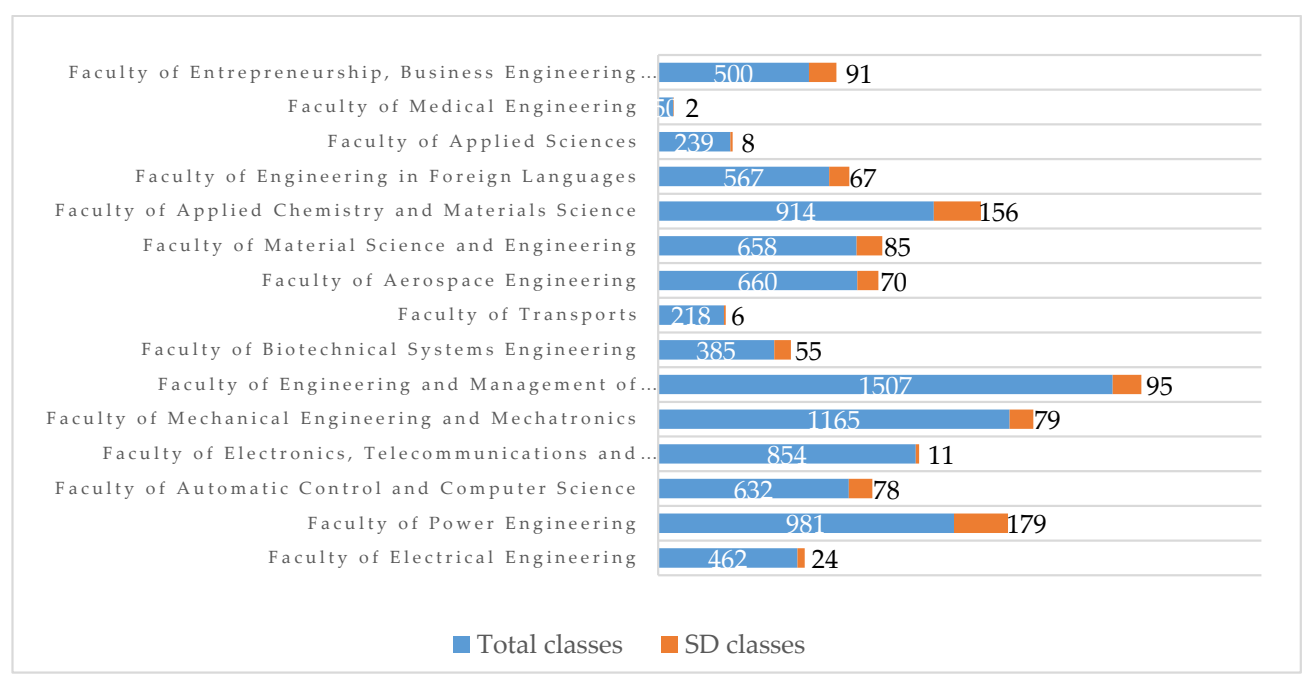

Figure 1. Distribution of SD classes from total SD class offering at Polytechnic University of Bucharest (UPB). 
Faculty of Engineering- Foreign Languages

Faculty of Railways Roads and Bridges

Faculty of Hydrotechnics

Faculty of Engineering Instalations

Faculty of Civil, Industrial and Agricultural Constructions

Total classes

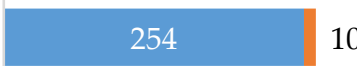

80 5

437

65

33

404

25

Figure 2. Distribution of SD classes from total SD class offering at Technical University of Civil Engineering of Bucharest (UTCB).

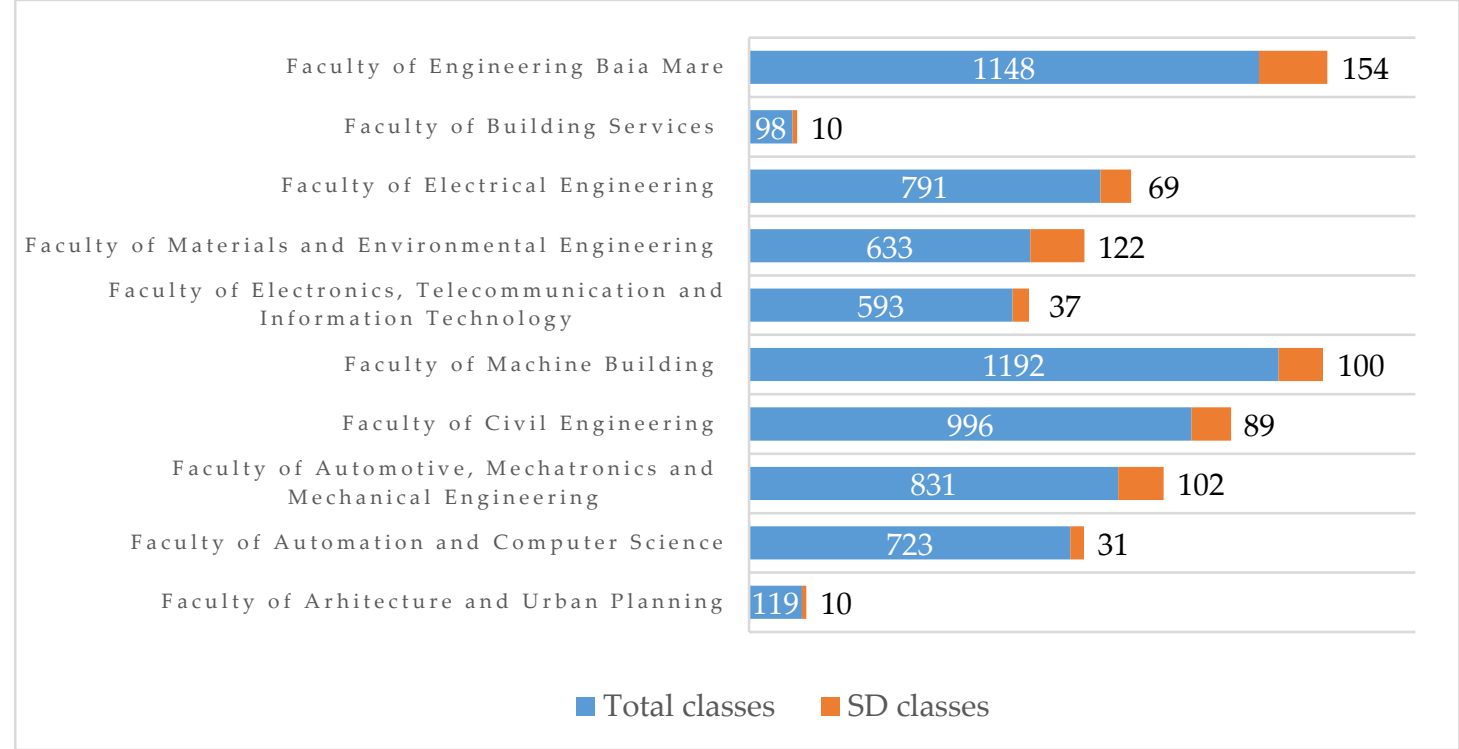

Figure 3. Distribution of SD classes from total SD class offering at Technical University of Cluj Napoca (TUCN). 


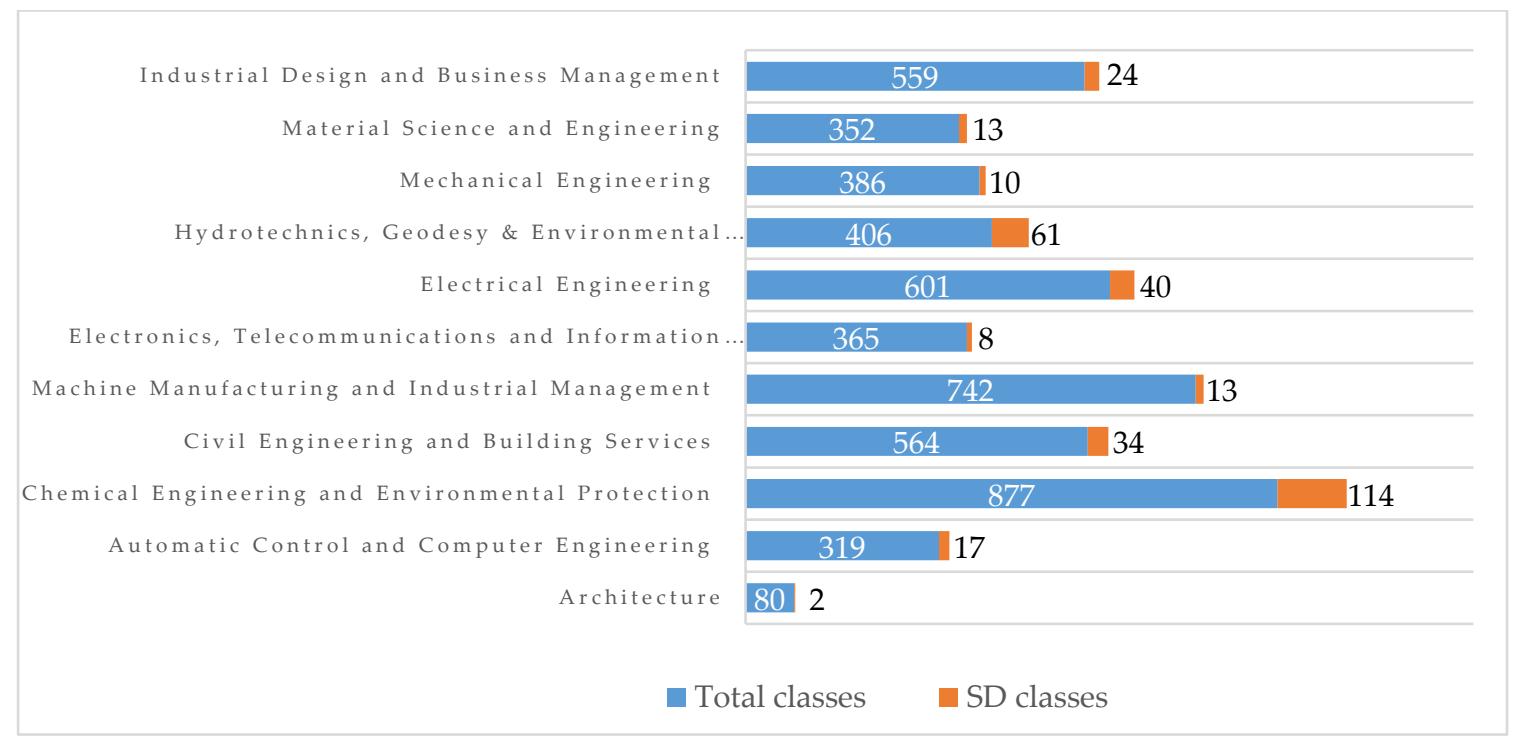

Figure 4. Distribution of SD classes from total SD class offering at Technical University “Gheorghe Asachi" Iasi (TUIASI).

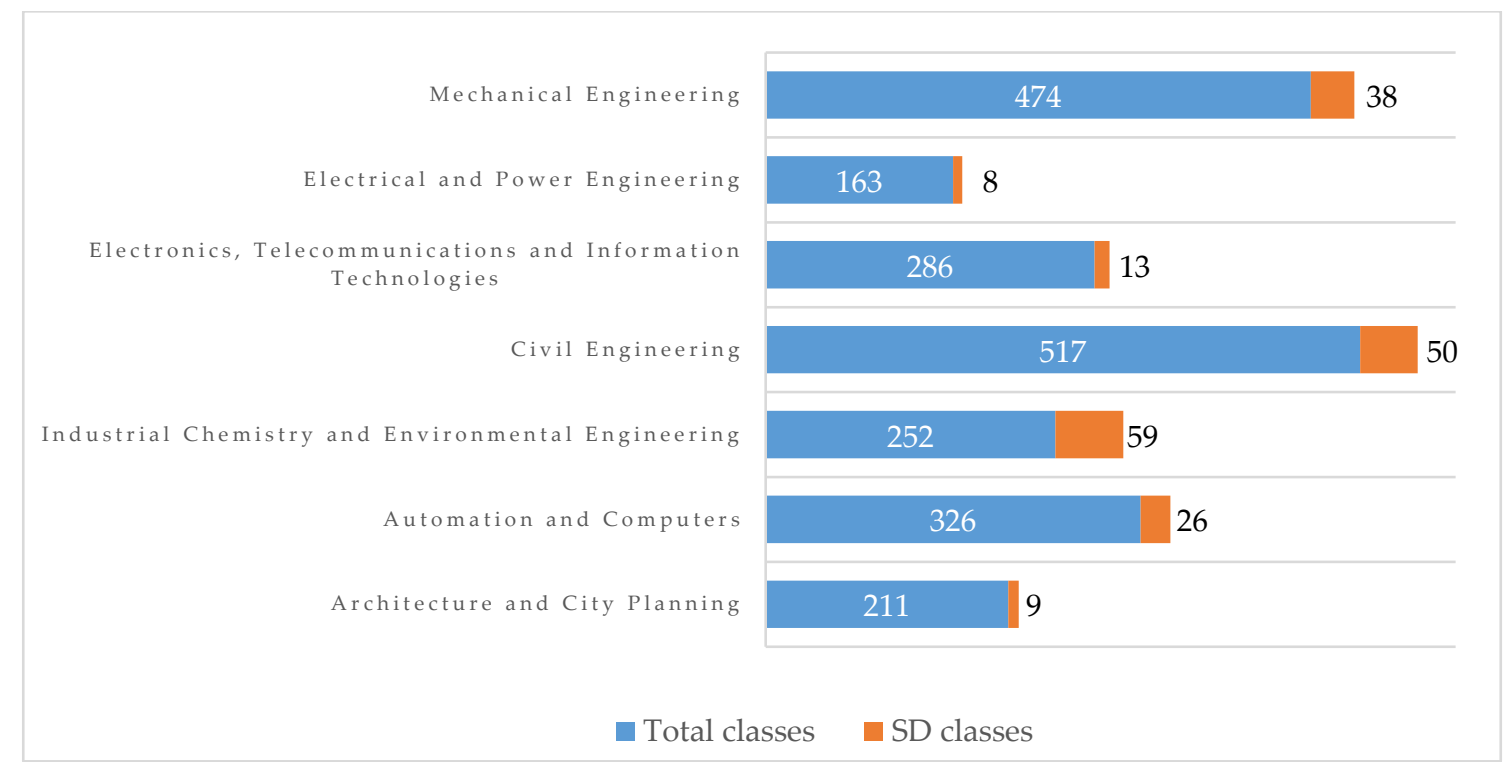

Figure 5. Distribution of SD classes from total SD class offering at Polytechnic University of Timisoara (UPT).

After analyzing each university with its faculties to see if there are any similarities between their study offer and their approach to sustainable development, we conclude that faculties that offer a greater number of SD classes have specializations, for both bachelor and master programs, centered on pollution, natural resources, recycling, reusing, ecology, ecosystem, and environment. The next step in our research was analyzing universities as a whole. As such, our research shows that these five universities offer a total number of 25,920 classes (bachelor and master) split as follows: 9792 classes at UPB, 7124 TUCN, 5251 TUIASI, 2229 UPT, and 1524 UTCB. From the total number of class offerings, UPB and TUCN offer around 10.3\% of SD-related classes, UPT and UTCB around 9.1\% while TUIASI offers a percentage of 6.4 SD classes. A clear overview over the way SD classes are split among the researched universities can be seen in Figure 6 (presenting an image over the total number of classes as well as SD classes for the five universities) and Figure 7 (presenting the way the SD classes are split between mandatory and optional classes at both bachelor and master levels for the five universities). 


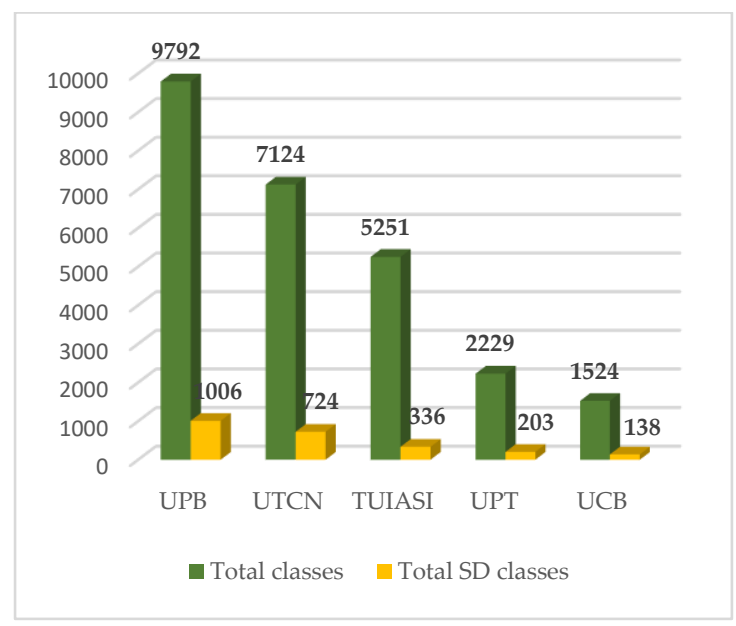

Figure 6. Total classes and total SD classes at the analyzed universities.

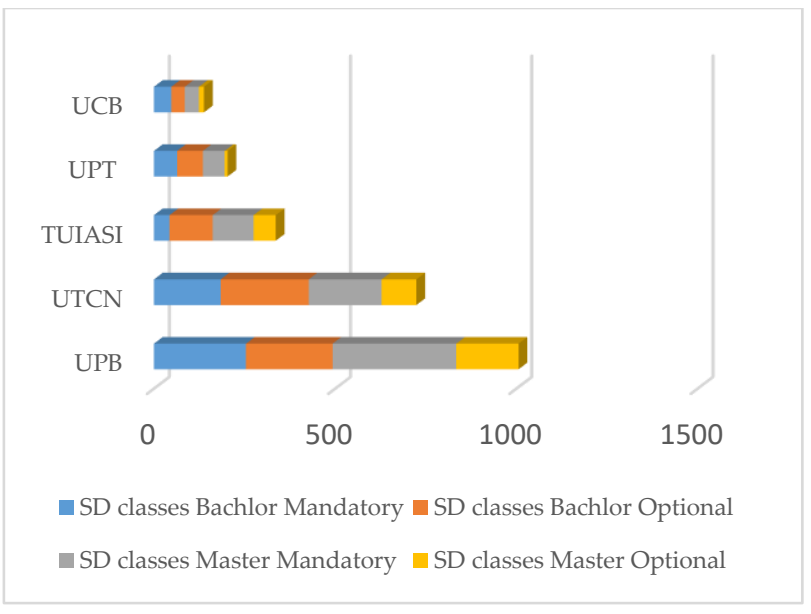

Figure 7. Distribution of SD classes on mandatory and optional classes at the analyzed universities.

Examining Figures 6 and 7 and Table 4, one can observe that while most (54.45\%) bachelor level $\mathrm{SD}$ courses are optional, there is an inverse relationship at the master level, meaning that most of the SD courses $(67.39 \%)$ are mandatory. The only exception here being UPB, were most of the SD classes offered are mandatory at both bachelor and master levels.

Table 4. Mandatory and optional SD classes offered at the analyzed universities.

\begin{tabular}{|c|c|c|c|c|c|c|c|c|c|c|}
\hline & \multicolumn{2}{|c|}{ UPB } & \multicolumn{2}{|c|}{ UTCB } & \multicolumn{2}{|c|}{ TUCN } & \multicolumn{2}{|c|}{ TUIASI } & \multicolumn{2}{|c|}{ UPT } \\
\hline SD classes Bachelor & \multicolumn{2}{|c|}{493} & \multicolumn{2}{|c|}{85} & \multicolumn{2}{|c|}{427} & \multicolumn{2}{|c|}{162} & \multicolumn{2}{|c|}{135} \\
\hline $\begin{array}{l}\text { - Mandatory } \\
\text { - Optional }\end{array}$ & $\begin{array}{l}\text { No. } \\
254 \\
239\end{array}$ & $\begin{array}{c}\% \\
51.52 \\
48.48\end{array}$ & $\begin{array}{c}\text { No. } \\
48 \\
37 \\
\end{array}$ & $\begin{array}{c}\% \\
56.47 \\
43.53\end{array}$ & $\begin{array}{l}\text { No. } \\
184 \\
243\end{array}$ & $\begin{array}{c}\% \\
43.09 \\
56.91\end{array}$ & $\begin{array}{c}\text { No. } \\
43 \\
119\end{array}$ & $\begin{array}{c}\% \\
26.54 \\
73.46 \\
\end{array}$ & $\begin{array}{c}\text { No. } \\
64 \\
71 \\
\end{array}$ & $\begin{array}{c}\% \\
47.41 \\
52.59 \\
\end{array}$ \\
\hline SD classes Master & \multicolumn{2}{|c|}{513} & \multicolumn{2}{|c|}{138} & \multicolumn{2}{|c|}{297} & \multicolumn{2}{|c|}{174} & \multicolumn{2}{|c|}{68} \\
\hline $\begin{array}{l}\text { - Mandatory } \\
\text { - Optional }\end{array}$ & $\begin{array}{l}\text { No. } \\
341 \\
172\end{array}$ & $\begin{array}{c}\% \\
66.47 \\
33.53\end{array}$ & $\begin{array}{c}\text { No. } \\
87 \\
51\end{array}$ & $\begin{array}{c}\% \\
63.04 \\
36.96\end{array}$ & $\begin{array}{c}\text { No. } \\
201 \\
96\end{array}$ & $\begin{array}{c}\% \\
67.68 \\
32.32\end{array}$ & $\begin{array}{c}\text { No. } \\
113 \\
61\end{array}$ & $\begin{array}{c}\% \\
64.94 \\
35.06\end{array}$ & $\begin{array}{c}\text { No. } \\
60 \\
8\end{array}$ & $\begin{array}{c}\% \\
88.24 \\
11.76\end{array}$ \\
\hline TOTAL & \multicolumn{2}{|c|}{1006} & \multicolumn{2}{|c|}{223} & \multicolumn{2}{|c|}{724} & \multicolumn{2}{|c|}{336} & \multicolumn{2}{|c|}{203} \\
\hline
\end{tabular}

When examining the total number of SD-related classes, we found that the majority of them are offered at the master level. An explanation of why the SD mandatory classes increase in number from bachelor to master can be due to the fact that Romanian master programs are more focused on certain topics (e.g., ecology, pollution, energy, entrepreneurship) and in the Romanian system, it is easier to 
add courses to the master curriculum than the bachelor one, making the master programs easier to adapt and adjust to the specific needs and expectations of the market.

One relevant aspect refers to the fact that all universities had classes with ethics in the title, mostly mandatory and at the master level, and this is due to an Order of the Ministry of education, which requires universities to include ethics and academic integrity courses in their curricula.

\section{Conclusions and Implications}

Education for sustainable development is a concept that has been debated upon by a lot of researchers $[14,16,17,22,28,34]$ based on the fact that: "An empowering education is one that builds the human resources we need to be productive, to continue to learn, to solve problems, to be creative, and to live together and with nature in peace and harmony. When nations ensure that such an education is accessible to all throughout their lives, a quiet revolution is set in motion: education becomes the engine of sustainable development (economic, social, moral, intellectual, and cultural) and the key to a better world" [65]. In this context, our research aimed to analyze and compare the engineering programs and courses of the Romanian technical universities in order to get a clearer view of the integration of sustainability-related topics. As previously mentioned, the analysis covered five universities, 48 faculties, 255 bachelor and 394 master programs.

We successfully collected curriculum data, scanned and analyzed 25,920 courses, and managed to create an image of the current status of SD-related topics integration in the curricula of Romanian technical universities: UPB and TUCN offer around 10.3\% of SD-related classes, UPT and UTCB around 9.1\% while TUIASI offer a percentage of 6.4 SD-related classes both at bachelor and master levels.

Based on our empirical analysis and findings we can make the following observations.

- The number of SD-related courses differs between universities and their faculties, with a minimum of one course and a maximum of 106 courses at the bachelor level and a minimum of one course and a maximum of 84 courses at the master level.

- $16.79 \%$ of the SD-related courses are being offered at the master level, while only $6.93 \%$ are offered at the bachelor level.

- There is also an important difference between the bachelor and master level SD class offerings, namely, at the bachelor level most of the SD-related courses are optional (54.45\%), while at the master level, the majority of SD-related courses are mandatory (67.39\%).

- Faculties which offer a greater number of SD classes have specializations, for both bachelor and master program, that are centered mainly on pollution, natural resources, recycling, reusing, ecology, ecosystem, and environment.

- One way to ensure systemic integration is through national centralized decision bodies, e.g., the ethics class included by all universities at the master level.

Our research was only an exploratory empirical content analysis focused on one element of 4C, namely, the curricula. However, we observed that currently, the analyzed technical universities in Romania are making small steps towards becoming sustainable universities, which, according to Velazquez et al. (2005) [28] and Lozano (2006) [66], is the way to go when trying to achieve sustainability at universities.

Our findings and the dissemination of our findings can have implications for both university/faculty administrators and educators and for business practitioners.

For university administrators, our findings allow stakeholders to compare the curriculum of their university with other institutions and/or to evaluate it according to EU, UN and other bodies' standards and recommendations regarding sustainability related topics in order to better adapt it both to the needs and expectations of the business environment and to the requirements of a more sustainable society. Therefore, this particular kind of study is necessary in order to increase the knowledge regarding the universities' efforts to pursuit education for sustainability. 
For faculty administrators and educators, the research provides insight into the sustainability-related classes offered within the university and can be a good starting point for change from a rather compartmentalized and siloed approach towards a more cooperative and trans-disciplinary perspective of the matter which would grant students access to SD-related classes from different schools than the one they are enrolled in.

For business practitioners, it can provide an image of the knowledge regarding sustainability their future employees have and so, they can calibrate their own internal training on SD-related topics.

Furthermore, the study provides a general image of the status of the curriculum for sustainability education in technical universities and is intended as a contribution to further stimulate the debate on the topic not only in academia, but also at a wider scale for policymakers in higher education.

\section{Limitations and Future Research}

Sustainability as an educational task has not been properly defined and is often considered too vague, distant, or abstract, and as a result, sustainability learning outcomes often lack clarity. As no universal formula for sustainability exists, sustainability-related education has been interpreted in different ways and this is consistent both with methodology and our findings as well.

Connected to this, one limitation can come from the highly inclusive definition of sustainability we adopted for the research and the inclusions of terms such as "ethics", "entrepreneurship", or "communication" which go further away from the more classic definitions which frame the concept of sustainability clearly to the core understanding as to the balance between economic growth, environmental carrying capacity, and sociocultural concerns $[60,67]$. Although this aspect can be considered a limitation, the research team sees it as a strength for two reasons: One is related to confirming the fact that there are diverse and somewhat divergent views over the concept which was confirmed during the research process among the team members as well, and the other one is connected to the changing educational needs for a more sustainable planet and a more sustainable way of life and entrepreneurial education is an important key in this process, as we adopted Bruyat and Julien (2001) constructivist approach which puts in the center of the entrepreneurial process the continuous dialog between the entrepreneur and the value created and the impact of/to the environment [68].

At the same time, our analysis focused solely on the content of the curricula and was limited to the information retrieved from the universities' public websites, so this stage of the research only provides information regarding the transmission of knowledge, without further analyzing the educational process which is paramount in developing the competences for sustainable development. In order to identify content aspects dedicated to sustainability-related issues embedded in other classes that did not have a suggestive title, and to classify those courses as partially dedicated to sustainable development, an in-depth analysis would have been required, as well as access to the course syllabus, which was possible in very few instances.

Future research will focus on a deeper understanding of sustainability integration, not only in terms of content, but also teaching process and methods by interviewing professors and students.

Author Contributions: Conceptualization: L.A., V.M. and A.Ș.; data curation: L.A., V.M., A.Ș. and R.C.; methodology L.A.; project administration: L.A. and V.M.; writing-original draft preparation: L.A., V.M., A.S.; writing-review and editing: L.A., V.M., A.S. and R.C. All authors have read and agreed to the published version of the manuscript.

Funding: This research received no external funding.

Conflicts of Interest: The authors declare no conflict of interest.

\section{References}

1. Wenz, L.; Levermann, A. Enhanced economic connectivity to foster heat stress-related losses. Science Advances 2016, 2, e1501026. [CrossRef] [PubMed] 
2. Disterheft, A.; Caeiro, S.; Azeiteiro, U.M.; Leal Filho, W. Sustainability Science and Education for Sustainable Development in Universities: A Way for Transition. In Sustainability Assessment Tools in Higher Education Institutions; Caeiro, S., Leal Filho, W., Jabbour, C., Azeiteiro, U.M., Eds.; Springer International Publishing: Cham, Switzerland, 2013; pp. 3-27. ISBN 978-3-319-02374-8.

3. United Nations. World Commission on Environment and Development. Our Common Future (The Brundtland Report). 1987. Available online: https://sustainabledevelopment.un.org/content/documents/ 5987our-common-future.pdf (accessed on 27 November 2019).

4. Council of the European Union. Renewed EU Sustainable Development Strategy (EU SDS). Brussels, 9 June 2006. Available online: https://register.consilium.europa.eu/doc/srv?l=EN\&f=ST\%2010117\%202006\%20INIT (accessed on 27 November 2019).

5. European Commission. EUROPE 2020: A Strategy for Smart, Sustainable and Inclusive Growth, Communication from the Commission, Brussels, 3.3.2010. Available online: https:/ec.europa.eu/eu2020/pdf/COMPLET\% 20EN\%20BARROSO\%20\%20\%20007\%20-\%20Europe\%202020\%20-\%20EN\%20version.pdf (accessed on 27 November 2019).

6. Ramos, G.I. The Sustainable Development Goals: A duty and an opportunity. In Debate the Issues: New Approaches to Economic Challenges; Love, P., Ed.; OECD Publishing: Paris, France, 2016; pp. 17-21.

7. Sibbel, A. Pathways towards sustainability through higher education. Int. J. Sustain. High. Educ. 2009, 10, 68-82. [CrossRef]

8. Celikdemir, Z.D.; Gunay, G.; Katrinli, A.; Penbek Alpbaz, S. Defining sustainable universities following public opinion formation process. Int. J. Sustain. High. Educ. 2017, 18, 294-306. [CrossRef]

9. UNESCO. United Nations Decade of Education for Sustainable Development (2005-2014): International Implementation Scheme. Paris, 2005. Available online: https://unesdoc.unesco.org/ark:/48223/pf0000139937 (accessed on 1 December 2019).

10. UNESCO. Education and the Search for a Sustainable Future. Policy Dialogue 1: ESD and Development Policy. 2009. Available online: https://unesdoc.unesco.org/ark:/48223/pf0000179121 (accessed on 27 November 2019).

11. Desha, C.J.; Hargroves, K.; Smith, M.H. Addressing the time lag dilemma in curriculum renewal towards engineering education for sustainable development. Int. J. Sustain. High. Educ. 2009, 10, 184-199. [CrossRef]

12. UNESCO. Available online: http://www.unesco.org/new/en/natural-sciences/science-technology/engineering/ sustainable-engineering/ (accessed on 27 November 2019).

13. Dowling, D.; Carew, A.; Hadgraft, R. Engineering Your Future: An. Australasian Guide; John Wiley \& Sons Australia, Ltd.: Brisbane, Australia, 2010; ISBN 9780470818169.

14. Rosen, M. Engineering Sustainability: A Technical Approach to Sustainability. Sustainability 2012, 4, 2270-2292. [CrossRef]

15. Lambrechts, W.; Mulà, I.; Ceulemans, K.; Molderez, I.; Gaeremynck, V. The integration of competences for sustainable development in higher education: An analysis of bachelor programs in management. J. Clean. Prod. 2013, 48, 65-73. [CrossRef]

16. Sady, M.; Zak, A.; Rzepka, K. The role of universities in Sustainability- Oriented Competencies Development: Insights from an Empirical Study on Polish Universities. Adm. Sci. 2019, 9, 62. [CrossRef]

17. García-Feijoo, M.; Eizaguirre, A.; Rica-Aspiunz, A. Systematic Review of Sustainable-Development-Goal Deployment in Business Schools. Sustainability 2020, 12, 440. [CrossRef]

18. Byrne, E.; Desha, C.; Fitzpatrick, J.; Hargroves, H. Engineering Education for Sustainable Development: A Review of International Progress. In 3rd International Symposium for Engineering Education; University College Cork: Cork, Ireland, 2010.

19. Davidson, C.I.; Hendrickson, C.T.; Matthews, H.S.; Bridges, M.W.; Allen, D.T.; Murphy, C.F.; Allenby, B.R.; Crittenden, J.C.; Austin, S. Preparing future engineers for challenges of the 21st century: Sustainable engineering. J. Clean. Prod. 2010, 18, 698-701. [CrossRef]

20. Lozano, F.J.; Lozano, R. Developing the curriculum for a new bachelor's degree in engineering for sustainable development. J. Clean. Prod. 2013, 64, 136-146. [CrossRef]

21. Watson, M.K.; Lozano, R.; Noyes, C.; Rodgers, M. Assessing curricula contribution to sustainability more holistically: Experiences from the integration of curricula assessment and students' perceptions at the Georgia institute of technology. J. Clean. Prod. 2013, 61, 106-116. [CrossRef]

22. Colombo, C.R.; Alves, A.C. Sustainability in engineering programs in a Portuguese Public University. Production 2017, 27. [CrossRef] 
23. Quelhas, O.L.G.; Lima, G.B.A.; Ludolf, N.V.-E.; Meiriño, M.J.; Abreu, C.; Anholon, R.; Rodrigues, L.S.G. Engineering education and the development of competencies for sustainability. Int. J. Sustain. High. Educ. 2019, 20, 614-629. [CrossRef]

24. Mesa, J.A.; Esparragoza, I.E.; Maury, H. Sustainability in engineering education: A literature review of case studies and projects. In Proceedings of the 15th LACCEI International Multi-Conference for Engineering, Education, and Technology, Boca Raton, FL, USA, 19-21 July 2017.

25. Bergsmann, E.; Schultes, M.-T.; Winter, P.; Schober, B.; Spiel, C. Evaluation of competence-based teaching in higher education: From theory to practice. Eval. Program Plan. 2015, 52, 1-9. [CrossRef]

26. Boccanfuso, D.; Larouche, A.; Trandafir, M. Quality of higher education and the labor market in developing countries: Evidence from an education reform in Senegal. World Dev. 2015, 74, 412-424. [CrossRef]

27. Hussain, T.; Eskildsen, J.; Edgeman, R.; Ismail, M.; Shoukry, A.M.; Gani, S. Imperatives of Sustainable University Excellence: A Conceptual Framework. Sustainability 2019, 11, 5242. [CrossRef]

28. Velazquez, L.; Munguia, N.; Sanchez, M. Deterring sustainability in higher education institutions. Int. J. Sustain. High. Educ. 2005, 6, 383-391. [CrossRef]

29. Beynaghi, A.; Trencher, G.; Moztarzadeh, F.; Mozafari, M.; Maknoon, R.; Leal Filho, W. Future sustainability scenarios for universities: Moving beyond the United Nations Decade of Education for Sustainable Development. J. Clean. Prod. 2016, 112, 3464-3478. [CrossRef]

30. Waas, T.; Verbruggen, A.; Wright, T. University research for sustainable development: Definition and characteristics explored. J. Clean. Prod. 2010, 18, 629-636. [CrossRef]

31. Association of University Leaders for a Sustainable Future-The Talloires Declaration 10 Point Action Plan. Available online: http://ulsf.org/wp-content/uploads/2015/06/TD.pdf (accessed on 27 November 2019).

32. Calder, W.; Clugston, R. International efforts to promote higher education for sustainable development. In Teaching Education for Sustainable Development at University Level, World Sustainability Series; Filho, W.L., Pace, P., Eds.; Springer International Publishing: Basel, Switzerland, 2016; pp. 162-174.

33. Jones, P.; Selby, D.; Sterling, S. More than the Sum of their Parts? Interdisciplinarity and Sustainability. In Sustainability Education: Perspectives and Practice across Higher Education; Jones, P., Selby, S., Sterling, S., Eds.; Earthscan: London, UK, 2010; ISBN 1844078779.

34. Velazquez, L.; Munguia, N.; Platt, A.; Taddei, J. Sustainable university: What can be the matter? J. Clean. Prod. 2006, 14, 810-819. [CrossRef]

35. Adams, R.; Martin, S.; Boom, K. University Culture and Sustainability: Designing and Implementing an Enabling Framework. J. Clean. Prod. 2018, 171, 434-445. [CrossRef]

36. Grecu, V.; Ipina, N. The Sustainable University-A Model for The Sustainable Organization. Manag. Sustain. Dev. Sibiu 2014, 6, 15-24. [CrossRef]

37. United Nations. Education Commitments Agenda 21-Chapter 36 \& UN Commission on Sustainable Development. 1992. Available online: https://www.iatp.org/sites/default/files/Education_Commitments_-_ Agenda_21_Chapter_36.htm (accessed on 3 December 2019).

38. UNESCO. Education for Sustainable Development Goals: Learning Objectives. 2017. Available online: https://unesdoc.unesco.org/ark:/48223/pf0000247444 (accessed on 4 December 2019).

39. Maloney, W.F.; Caicedo, F.V. Engineering Growth: Innovative Capacity and Development in the Americas; World Bank Research Publication: Washington, DC, USA, 2017; Available online: http://pubdocs.worldbank.org/en/ 422491458852358129/Engineers-County7A.pdf (accessed on 23 December 2019).

40. Azapagic, A.; Perdan, S.; Shallcross, D. How much do engineering students know about sustainable development? The findings of an international survey and possible implications for the engineering curriculum. Eur. J. Eng. Educ. 2005, 30, 1-19. [CrossRef]

41. Sterling, S.; Thomas, I. Education for sustainability: The role of capabilities in guiding university curricula. Int. J. Innov. Sustain. Dev. 2006, 1, 349. [CrossRef]

42. Riley, D.R.; Grommes, A.V.; Thatcher, C.E. Teaching sustainability in building design and engineering. J. Green Build. 2007, 2, 175-195. [CrossRef]

43. Lozano, R. Diffusion of sustainable development in universities' curricula: An empirical example from Cardiff University. J. Clean. Prod. 2010, 18, 637-644. [CrossRef]

44. Boks, C.; Diehl, J.C. Integration of sustainability in regular courses: Experiences in industrial design engineering. J. Clean. Prod. 2006, 14, 932-939. [CrossRef] 
45. Abdul-Wahab, S.A.; Abdulraheem, M.Y.; Hutchinson, M. The need for inclusion of environmental education in undergraduate engineering curricula. Int. J. Sustain. High. Educ. 2003, 4, 126-137. [CrossRef]

46. Kamp, L. Engineering education in sustainable development at Delft University of Technology. J. Clean. Prod. 2006, 14, 928-931. [CrossRef]

47. Thomas, I. Sustainability in tertiary curricula: What is stopping it happening? Int. J. Sustain. High. Educ. 2004, 5, 33-47. [CrossRef]

48. Mulder, K.F. Engineering curricula in sustainable development. An evaluation of changes at Delft University of Technology. Eur. J. Eng. Educ. 2006, 31, 133-144. [CrossRef]

49. Huntzinger, D.N.; Hutchins, M.J.; Gierke, J.S.; Sutherland, J.W. Enabling sustainable thinking in undergraduate engineering education. Int. J. Eng. Educ. 2007, 23, 218-230.

50. Tejedor, G.; Segalàs, J.; Rosas-Casals, M. Transdisciplinarity in higher education for sustainability: How discourses are approached in engineering education. J. Clean. Prod. 2018, 175, 29-37. [CrossRef]

51. Sánchez-Carracedo, F.; Moreno-Pino, F.M.; Sureda, B.; Antúnez, M.; Gütierrez, I. A Methodology to Analyze the Presence of Sustainability in Engineering Curricula. Case of Study: Ten Spanish Engineering Degree Curricula. Sustainability 2019, 11, 4553. [CrossRef]

52. Allen, D.; Allenby, B.; Bridges, M.; Crittenden, J.; Davidson, C.; Hendrickson, C.; Matthews, C.; Murphy, C.; Pijawka, D. Benchmarking Sustainability Engineering Education: Final Report; Centre for Sustainable Engineering: Pittsburgh, PA, USA, 2008.

53. Byrne, E.P.; Desha, C.J.; Fitzpatrick, J.J.; “Charlie” Hargroves, K. Exploring sustainability themes in engineering accreditation and curricula. Int. J. Sustain. High. Educ. 2013, 14, 384-403. [CrossRef]

54. Pappas, E.; Pappas, J. A behavioral approach to building cognitive foundations for effective thought and action. Innov. High. Educ. 2011, 36, 359-372. [CrossRef]

55. Allenby, B.; Folsom Murphy, C.; Allen, D.; Davidson, C. Sustainable engineering education in the United States. Sustain. Sci. 2009, 4, 7. [CrossRef]

56. Bjornberg, K.E.; Skogh, I. Integrating social sustainability in engineering education at the KTH royal institute of technology. Int. J. Sustain. High. Educ. 2015, 16, 639-649. [CrossRef]

57. Christ, J.A.; Heiderscheidt, J.L.; Pickenpaugh, M.Y.; Phelan, T.J.; Pocock, J.B.; Stanford, M.S.; Twesme, T.M. Incorporating Sustainability and Green Engineering into a Constrained Civil Engineering Curriculum. J. Prof. Issues Eng. Educ. Prat. 2015, 141. [CrossRef]

58. Rose, G.; Ryan, K.; Desha, C. Implementing a holistic process for embedding sustainability: A case study in first year engineering, Monash University, Australia. J. Clean. Prod. 2015, 106, 229-238. [CrossRef]

59. Romanian Ministry of Education. Report regarding the Higher Education Status in Romania 2017-2018. Available online: https://www.edu.ro/sites/default/files/Raport $\% 20$ privind $\% 20$ starea $\% 20 \% \mathrm{C} 3 \% \mathrm{AEnv} \% \mathrm{C} 4 \%$ 83\%C8\%9B\%C4\%83m\%C3\%A2ntului\%20superior\%20din\%20Rom\%C3\%A2nia_\%202017\%20-2018.pdf (accessed on 4 December 2019).

60. Wu, Y.-C.J.; Huang, S.; Kuo, L.; Wu, W.-H. Management Education for Sustainability: A Web-Based Content Analysis. Acad. Manag. Learn. Educ. 2010, 9, 520-531. [CrossRef]

61. Mulder, K. Engineering education in sustainable development: Sustainability as a tool to open up the windows of engineering institutions. Bus. Strateg. Environ. 2004, 13, 275-285. [CrossRef]

62. Khan, T. Sustainability accounting courses, Talloires Declaration and academic research. Int. J. Sustain. High. Educ. 2013, 14, 42-55. [CrossRef]

63. Mustaţă, R.V.; Bonaci, C.G.; Hintea, C.; Neamţu, B. Business education for sustainable development: The case of Romanian universities. Amfiteatru Econ. J. 2013, 15, 802-818.

64. O’Byrne, D.; Dripps, W.; Nicholas, K.A. Teaching and learning sustainability: An assessment of the curriculum content and structure of sustainability degree programs in higher education. Sustain. Sci. 2015, 10, 43-59. [CrossRef]

65. Power, C. The Power of Education: Education for All, Development, Globalisation and UNESCO; Springer: London, UK, 2015.

66. Lozano, R. Incorporation and institutionalization of SD into universities: Breaking through barriers to change. J. Clean. Prod. 2006, 14, 787-796. [CrossRef]

67. Hopwood, B.; Mellor, M.; O’Brien, G. Sustainable development: Mapping different approaches. Sustain. Dev. 2005, 13, 38-52. [CrossRef] 
68. Bruyat, C.; Pierre-Andre, J. Defining the field of research in entrepreneurship. J. Bus. Ventur. 2001, 16, 165-180. [CrossRef]

(). (1)

(C) 2020 by the authors. Licensee MDPI, Basel, Switzerland. This article is an open access article distributed under the terms and conditions of the Creative Commons Attribution (CC BY) license (http://creativecommons.org/licenses/by/4.0/). 